\title{
The Relationship between Learning Motivation and Emotional Intelligence with Physics Learning Achievement of Public High School Students Class XI MIA in Singaraja City
}

\author{
Putu Ratni Ayu Utami, I Wayan Santyasa, Ni Ketut Rapi \\ Physics Education Universitas Pendidikan Ganesha \\ Correspondence: J1. Udayana 11 Singaraja Bali. \\ ratniayu88@gmail.com
}

\begin{abstract}
This research aimed to analyzing the relationship between learning motivation and physics learning achievement, emotional intelligence and physics learning achievement, and learning motivation and emotional intelligence with physics learning achievement at SMA Negeri in Singaraja city. The type of this research was ex-post facto with correlation quantitative method. The result of this research was the students' physics learning achievement which is low and it shows that there are the positive relationship between learning motivation and emotional intelligence with physics learning achievement.
\end{abstract}

Keywords: learning motivation, emotional intelligence, learning achievement

\begin{abstract}
Abstrak: Penelitian ini bertujuan untuk menganalisis hubungan motivasi belajar dan prestasi belajar fisika, kecerdasan emosional dan prestasi belajar fisika serta motivasi belajar dan kecerdasana emosional dengan prestasi belajar fisika di SMA Negeri di Kota Singaraja. Jenis penelitian ini adalah ex-post facto dengan metode kuantitatif korelasional. Hasil penelitian menemukan bahwa prestasi belajar fisika siswa berada pada kategori rendah dan menunjukkan adanya hubungan positif antara motivasi belajar dan kecerdasan emosional terhadap prestasi belajar fisika.
\end{abstract}

Kata kunci: motivasi belajar, kecerdasan emosional, prestasi belajar

Education which is developed in the globalization era experienced a very rapid increase caused by technology advancement. It has an impact on human resources that must also go with the development of existing technology. Education as a learning process that aims to develop students' self-potentials in supporting the development of country's technology and natural resources.

The quality of education indicates the quality of human resources, so education needs to be given early to be able to construct intelligent, pious, noble people, and have good personalities and can behave according to suitable norms. The development of the quality of human resources through optimization in education refers to Law No. 20 of 2003 concerning the National Education System which states that the aim of national education is to develop students' potential to become human beings who believe in God and fear of God Almighty, have good morality, be healthy, knowledgeable, capable, creative, independent, and become democratic citizen and to be responsible. Education will also develop maturity, independence, good attitude and high learning discipline. In correspondence with these educational goals, students are expected to be able to obtain good learning achievements in the learning process so that they can develop their abilities to have intelligence, skills, religious spiritual strength, and self-control or emotions. The quality of human resources is reflected in student's achievement in learning and ability in mastering technological development, thus it can characterize an increase of the quality of education.

Learning achievement is a change in attitude and behavior after receiving a lesson or after learning something (Hamalik, 2001). Furthermore, Soemanto (2003) states that knowing someone's learning achievement is important, because by knowing the results that have been achieved then students will 
try to improve their learning achievement. One of the learning achievements that should be improved is physics learning achievement. Physics is the study of natural phenomena and underlies the development of technology, therefore physics provides learning for humans to live in harmony with natural law. According to the Ministry of Education and Culture (2014) the learning objectives of physics contained in the 2013 curriculum framework which are mastering concepts and principles as well as mastering the skills of developing knowledge and self-confidence as a basis for continuing education at a higher level and developing science and technology. The development of physics is not only intended for individual human needs, but also humans in general, for the country and even the world (Santyasa, 2014).

Based on the explanation above, it is obvious that physics learning achievement becomes important to improve the development of a nation and state. Various attempts have been made to improve the quality of national education, for example the development of national and local curriculum, improvement of teachers' competence through training, supply of books and teaching aids, improvement of educational facilities and infrastructure, and improvement of the quality of school management (Daud, 2012). Students should be encouraged to achieve high learning achievement, especially in physics under the reason of the importance of nation's hope to improve the quality of education.

However, in reality, physics learning achievement still has not met the expectations yet. Based on the World Education Ranking published by the Organization for Economic Co-operation and Development (OECD), Indonesia ranks 57th out of 65 countries with a score on the 383 on natural science test. The results of the survey of Program for International Student Assessment (PISA) in 2016 about achievements in literacy, mathematics and science from 65 countries. Achievement of students in physics learning can be reflected through the national exam scores in physics subject. The average score of national exam for all physics subjects in Singaraja High Schools in 2017 and 2018 were 46.06 and 50.98 (Kemendikbud, 2018). Based on these data, it can be concluded that physics learning achievement of state high schools in Singaraja City is in the low category. The analysis of the findings above reinforces the fact that physics learning achievement is low.

In some way, physics learning achievement in Indonesia should be increased. However, there is a gap between expectation and reality which shows that there are problems in improving physics learning achievement. Factors that influence physics learning achievement are internal factors that originate from students, such as intelligence or emotional perception, attention, talent, interest, motivation, maturity, readiness and fatigue, while external factors that originate from outside of students, like the family environment, school environment and community environment (Slameto, 2003). Agreeing that, Sikhwari (2017) revealed that motivation is not the only factor influencing the level of learning achievement. Other factors that influence students' achievement are psychological factors, like emotional intelligence. Starting from the statement, it can be concluded that the achievement of students tend to be influenced by factors originating from within the students themselves, one of them is psychological factors of students. According to Suryabrata (2011) psychological factors of students consist of interests, motivation, personality variables, and cognitive abilities including special abilities or talents, general abilities or intelligence.

Nur (2003) states that motivation as an internal process of a person who activates, guides, and maintain behavior within a certain time span. According to Ramirez et al. (2018) motivation plays an important role in learning achievement. Achievements will be better if they have high motivation. Agreeing with this, Yuliawan (2016) revealed that in learning activities, the motivation can be said to be a driving force within students that increase learning activities and gives direction to learning activities, so the desired goals can be achieved by students. This statement is supported by Muwonge et al. (2018) by stating that students who do not have the motivation to learn will not be able to organize their learning efforts systematically, thus, when students do not understand the material given, they will not ask for help. This indicates that students' interest in this subjects is low so students are not motivated to solve problems in the lesson. Agustina and Yuliana (2018) stated that motivation for learning is important in conducting learning activities because motivation is a motivator that can trigger someone to do some activities. The goals to be achieved can be a motivational tool that impose someone to do activities, including learning. This statement gives meaning that learning motivation is the reason behind academic activities carried out by students and becomes a predictor in achieving learning goals that will lead to students' achievement. 
Intelligence is something that is possessed by every student, the only difference is the level of intelligence between students. That is because students who have a high level of intelligence will be more successful than students who have low level of intelligence. Intelligence in regulating emotions is classified into emotional intelligence. According to (Daud, 2012) emotional intelligence (EI) is a characteristic of a person which classified as a type of intelligence that really needs to be improved. EI is a driving force that can cause aspects of energy, strength, endurance, and stamina. Similar to learning motivation, emotional intelligence can also be used as a predictor of students' achievement (Asry et al., 2017). Liu and Surat (2017) revealed that students with high intelligence ability but they obtain relatively low learning achievement, meanwhile students with relatively low intelligence ability can achieve high learning achievement. This indicates that a person is not enough to only have an IQ (Intelligence Quotient), but ideally is that IQ balanced with EI (Emotional Intelligence). Without emotional intelligence, students will not be able to use their cognitive abilities according to their potential. In general, pure people only have high academic intelligence. They tend to have an unreasonable anxiety, are too critical, are fussy, tend to withdraw, seem cold and tend to be difficult to express their frustration and anger appropriately. When it is supported by the low level of emotional intelligence, then people like this often becomes a source of problems. Based on the above characteristics, if a person has high IQ but low level of emotional intelligence, this person tends to be seen as a stubborn person, difficult to get along, easily frustrated, not easily to trust others, not sensitive to environmental conditions and tend to despair if he or she experiences stress. The opposite condition is experienced by a person who has an average IQ level but have high emotional intelligence. In essence, emotional intelligence is the ability to recognize our own feelings and the feelings of others, the ability to motivate oneself, and the ability to manage emotions well in ourselves and in relationships with others (Goleman, 2003). According to Pekrun (in Ramirez et al., 2018) states that emotions associated with activities and learning outcomes that can affect learning achievement. Emotional intelligence (emotion) which is negative affects the desire to excel in lack of learning. In accordance with this opinion, one of the causes of low students' achievement is the influence of learning motivation and emotional intelligence. Intelligence must be developed with various techniques in order to improve students' understanding abilities, reflect on themselves and their attention, so that students' learning achievement will increase. Based on the explanation above, it can be said that there is an influence of learning motivation and emotional intelligence on students' achievement.

The main problems examined in this study are: (1) Is there a relationship between learning motivation and physics learning achievement in class XI MIA in state high schools in Singaraja?; (2) Is there a relationship between emotional intelligence and physics learning achievement of students in class XI MIA at SMA Negeri Singaraja ?; and (3) Is there a relationship between learning motivation and emotional intelligence with the physics learning achievement of students in class XI MIA at SMA Negeri Singaraja? Thus, the objectives of this study are: (1) To describe the relationship between learning motivation and physics learning achievement of students in class XI MIA in state high schools in Singaraja City; (2) Describe the relationship between emotional intelligence and physics learning achievement of XI MIA grade students of SMA Negeri in Singaraja; and (3) Describe the relationship between learning motivation and emotional intelligence with the physics learning achievement of XI MIA grade students of SMA Negeri in Singaraja City.

\section{METHOD}

This study used a correlational research design. The research design used was ex post facto research design. The variables used in this study were independent variables such as learning motivation and emotional intelligence and the dependent variable was students' achievement. This research was conducted in the State High School in Singaraja with the population of the study was all students of class XI MIA, with the total 789 students. The sample collection technique used was proportional random sampling with a sample size of 303 students.

The data collection instrument used was a questionnaire to obtain data on learning motivation and emotional intelligence as well as physics learning achievement tests to obtain student physics learning achievement data. Correlation analysis using SPSS was used to test the relationship of learning motivation with physics learning achievement, emotional intelligence with physics learning achievement, and the relationship between learning 
motivation and emotional intelligence with physics learning achievement. Data obtained through questionnaires and physics learning achievement tests will be processed using a Likert scale (1-5).

\section{RESULTS AND DISCUSSION}

Based on the results of the study, an average score of students' learning motivation was obtained as 102.91 which is classified in the medium category. Data for emotional intelligence showed that the average students' score of 105.02 which belongs to the medium category. The results of the analysis of students' physics learning achievement score showed an average value of 53.75 students which belongs to the low category.

Learning motivation scores obtained by students who were qualified into the conversion of absolute scores on a scale of five, such as students with very high score which consist of 8 people with a percentage of $2.64 \%$ of the total sample of students who answered the learning motivation questionnaire. Students who scored with a high category were 96 people with a percentage of $31.68 \%$ of the total sample of students who answered the learning motivation questionnaire. Students who scored in the medium category were 156 people with a percentage of $51.49 \%$ of the total sample of students who answered the learning motivation questionnaire. Students who scored in the low category were 36 people with a percentage of $11.88 \%$ of the total sample of students who answered the learning motivation questionnaire. Students who scored in the very low category were 7 people with a percentage of $2.31 \%$ of the total sample of students who answered the learning motivation questionnaire.

Description of the average score for each dimension of learning motivation, the first dimension (the trigger to achieve something) had an ideal maximum score of 30 and an average score of 21.05. The conversion score on this dimension was 115.75 with a high category. The second dimension (commitment) had an ideal maximum score of 30 , an average score of 18.41 , and a conversion score of 101.23 in the medium category. The third dimension (initiative) had an ideal maximum score of 65 , an average score of 37.82 , and a conversion score of 96.01 in the medium category. The fourth dimension (optimistic) had an ideal maximum score of 40 , an average score of 25.63 , and a conversion score of 105.73 in the medium category.

The findings of learning motivation for students of class XI MIA of state high schools in Singaraja
City indicate that the level of student motivation which is moderate, thus it must be improved. However, if it was reviewed based on conversion scores per dimension of learning motivation, it was found that the third dimension (initiative) had the lowest score which indicates that the students must take the initiative to achieve goals.

Emotional intelligence scores obtained by students who qualified into the conversion of absolute scores on a scale of five, such as students who scored a very high category consisted of 22 people with a percentage of $7.26 \%$ of the students' sample who answered the emotional intelligence questionnaire. Students who scored with a high category were 128 people with a percentage of $42.24 \%$ of the total sample of students who answered the emotional intelligence questionnaire. Students who scored in the medium category were 126 people with a percentage of $41.58 \%$ of the total sample of students who answered the emotional intelligence questionnaire. Students who got low category scores were 24 people with a percentage of $7.92 \%$ of the total sample of students who answered the emotional intelligence questionnaire. Students who got very low score with the total 3 people with a percentage of $0.99 \%$ of the total sample of students who answered emotional intelligence.

Description of the average score for each dimension of emotional intelligence, namely the first dimension (emotional identification) had an ideal maximum score of 35 and an average score of 24.38. The conversion score on this dimension was 111.46 with a high category. The second dimension (emotional use) had a maximum score of 45 and an average score of 29.28. The convergence score on this dimension was 104.10 in the medium category. The third dimension (emotional understanding) had a maximum score of 45 and an average score of 29.05 . The conversion score on this dimension was 103.28 with a medium category. The fourth dimension (emotional regulation) had a maximum score of 35 and an average score of 23.31. The conversion score on this dimension was 102.00 in the medium category.

These findings indicate that the emotional intelligence of the 11th grade students of Mathematics and Natural Sciences in all State High Schools in Singaraja City is in the moderate category, so it needs to be developed to become a high category. However, when the conversion scores were reviewed per dimension of emotional intelligence of students, it was found that the dimensions of emotional 
regulation had the lowest score compared to the other four dimensions of emotional intelligence. This means that students must be able to control emotions in more positive direction because the regulation of emotions becomes one of the strong foundations to be more success in achieving goals.

Physics achievement scores obtained by students were converted into a scale of 100 and categorized based on benchmark reference assessment (PAP), for example students who got a very high category were 4 students with a percentage of $1.32 \%$ of the total sample of students who answered the physics learning achievement test. Students who obtained high category were 36 people with a percentage of $11.88 \%$ of the total sample of students who answered the physics learning achievement test. Students who obtained the medium category were 101 people with a percentage of $33.33 \%$ of the total sample of students who answered physics learning achievement tests. Students who got low category were 110 people with a percentage of $36.30 \%$ of the total sample of students who answered the physics learning achievement test. Students who obtained the very low category were 52 people with a percentage of $17.16 \%$ of the total sample of students who responded to the physics learning achievement test.

Description of the score of each dimension of learning achievement is provided in a more detailed explanation of students' physics learning achievement which shows that the knowledge dimension obtained an average value for the conceptual sub dimensions of 39.06 and a conversion value of 44.64 with a low category. In addition, in the procedural dimension chapter, the average value was 26.06 and the conversion value was 26.06 with a very low category. Furthermore, in the cognitive process dimension for the understanding sub-dimension $(\mathrm{C} 2)$ obtained an average value of 7.23 and a conversion value of 57.82 were in the medium category, applying $(\mathrm{C} 3)$ obtained an average value of 7.67 and a conversion value of 40.89 with a low category, analyzing (C4) obtained an average value of 24.17 and a conversion value of 42.96 with a low category, and evaluating (C5) obtained an average value of 3.26 with a conversion value of 26,06 with a very low category.

Based on these findings, it can be seen that both the dimensions of knowledge and cognitive processes, the average value of students is dominated by the low category. This indicates that the physics learning achievement of the $11^{\text {th }}$ grade students of Mathematics and Natural Sciences in all State High Schools in Singaraja really needs more serious attention from various parties which are involved in the world of education to be further improved in accordance with studies on the 2013 Curriculum.

Based on the assumption tests that have been fulfilled, therefore the hypothesis test can be done. A summary of the results of the linear regression test for one predictor and the multiple regression test for two predictors are presented in Table 1.

\section{Tabel 1. Summary of Regression Test Results}

\begin{tabular}{lcccc}
\hline $\begin{array}{c}\text { Variable } \\
\text { Pairs }\end{array}$ & $\mathbf{F}_{\text {count }}$ & $\mathbf{R}$ & $\mathbf{R}^{\mathbf{2}}$ & $\begin{array}{c}\text { SE } \\
(\%)\end{array}$ \\
\hline $\mathrm{X}_{1} \rightarrow \mathrm{Y}$ & 20,69 & 0,25 & 0,06 & 5,82 \\
\hline $\mathrm{X}_{2} \rightarrow_{\mathrm{Y}}$ & 9,55 & 0,18 & 0,03 & 1,18 \\
\hline $\begin{array}{l}\mathrm{X}_{1} \text { and } \mathrm{X}_{2} \\
\rightarrow \mathrm{Y}\end{array}$ & 10,51 & 0,26 & 0,07 & 7,00 \\
\hline
\end{tabular}

Based on Table 1, the regression test between predictor $\mathrm{X}_{1}$ (learning motivation) and criterion $\mathrm{Y}$ (physics learning achievement) obtained $\mathrm{F}_{\text {count }}$ of 20.69. The significant level used was $5 \%$ with a degree of freedom of numerator 1 and the degree of freedom of the denominator 301 which obtained a $\mathrm{F}_{\text {table }}$ value of 3.89. If $\mathrm{F}_{\text {count }}$ is compared to $\mathrm{F}_{\text {table }}$, we get $\mathrm{F}_{\text {count }}>\mathrm{F}_{\text {table }}$ (Ho is rejected and Ha is accepted). This result means that there is a positive relationship between learning motivation and physics learning achievement of students in class XI MIA at SMA Negeri Singaraja.

Score of $\mathrm{R}^{2}$ (R Square) of 0.06 showed that $6 \%$ of the physics learning achievement variables can be explained by changes in learning motivation variables. The effective contribution of learning motivation variables to physics learning achievement of $5.82 \%$ stated that the contribution of predictor $\mathrm{X}_{1}$ (learning motivation) to criterion $\mathrm{Y}$ (physics learning achievement) was only $5.82 \%$ and the remaining $94.18 \%$ was the accumulation of contributions from emotional intelligence variables and other variables that was not examined in this study.

Variations in the contribution of physics learning achievement variables can be explained by learning motivation variables through the regression equation $\widehat{Y}=29.67+0.23 \mathrm{X}_{1}$. This regression equation meant that each improvement of $X_{1}$ predictor was value one unit, the criterion value ${ }^{\widehat{Y}}$ will increase by 0.23 units. These results illustrate the high and low of students' physics learning achievement which is caused by students' motivation that predict the regression 
equation.

Based on Table 1, a regression test between predictors $\mathrm{X}_{2}$ (emotional intelligence) and criterion $\mathrm{Y}$ (physics learning achievement) obtained a $\mathrm{F}_{\text {count }}$ value of 9.55. The significance level used was $5 \%$ with a degree of freedom of numerator 1 and the degree of freedom of the denominator 301 obtained a $\mathrm{F}_{\text {table }}$ value of 3.89. If $\mathrm{F}_{\text {count }}$ is compared with $\mathrm{F}_{\text {table }}$, then get $\mathrm{F}_{\text {count }}>\mathrm{F}_{\text {table }}$ (Ho is rejected and Ha is accepted). These results indicate that there is a positive relationship between emotional intelligence and physics learning achievement of students in class XI MIA at SMA Negeri Singaraja.

Score of $\mathrm{R}^{2}$ (R Square) of 0.03 indicated that $3 \%$ of physics learning achievement variables can be explained by changes in emotional intelligence variables. The effective contribution of the variable emotional intelligence to physics learning achievement of $1.18 \%$ stated that the contribution of predictor $\mathrm{X}_{2}$ (emotional intelligence) to criterion $\mathrm{Y}$ (physics learning achievement) was only $1.18 \%$, the remaining $98.82 \%$ was the accumulation of contributions from the variable emotional intelligence and other variables which was not examined in this study.

Variations in the contribution of physics learning achievement variables can be explained by emotional intelligence variables through the regression equation $\widehat{Y}=35.75+0.16 \mathrm{X}_{2}$. This regression equation indicated that each improvement of $\mathrm{X}_{1}$ predictor was value one unit, the criterion value of $\widehat{Y}$ will increase by 0.16 units. These results illustrate that the high and low students' physics learning achievement is caused by the emotional intelligence of students which is predicted by the regression equation.

Based on Table 1, multiple regression test between predictor $\mathrm{X}_{1}$ (learning motivation) and predictor $\mathrm{X}_{2}$ (emotional intelligence) with criterion $\mathrm{Y}$ (physics learning achievement) obtained a $\mathrm{F}_{\text {count }}$ value of 10.51 . The significant level used was $5 \%$ with a degree of freedom of numerator 2 and the degree of freedom of the denominator 301 obtained $\mathrm{F}_{\text {table }}$ value of 3.04. If $\mathrm{F}_{\text {count }}$ is compared with $\mathrm{F}_{\text {table }}$ obtained $\mathrm{F}_{\text {count }}>\mathrm{F}_{\text {table }}$ (Ho is rejected and $\mathrm{Ha}$ is accepted). These results indicate there is a positive relationship together between learning motivation and emotional intelligence with physics learning achievement of students of class XI MIA in SMA Negeri Singaraja.

$\mathrm{R}^{2}$ (R Square) of 0.07 means that $7 \%$ of physics learning achievement variables can be explained by changes in learning motivation and emotional intelligence variables. The effective contribution of variables of learning motivation and emotional intelligence together to physics learning achievement of $7 \%$ stated that the contribution of predictors $X_{1}$ (learning motivation) and $\mathrm{X}_{2}$ (emotional intelligence) to criterion Y (physics learning achievement) was only $7 \%$ while the remaining $93 \%$ was accumulation of contributions from other variables not examined in this study.

Variations in the contribution of physics learning achievement variables can be explained by variables of learning motivation and emotional intelligence through the regression equation $\widehat{Y}=27,80$ $+0,20 X_{1}+0,04 X_{2}$. This regression equation meant that each additional predictor value of $X_{1}$ and $X_{2}$ was one unit each, then the criterion value $\widehat{Y}$ will increase by 0.04 units. These results illustrate that the level of physics learning achievement of students is caused by students' motivation and emotional intelligence predicted by the regression equation.

Based on descriptive analysis, it was found that the level of learning motivation of class XI MIA of high school students in Singaraja City was generally in the medium category. However, if it is analyzed based on scores per dimension, the dimensions of encouragement to achieve something were in the high category, while the dimensions of commitment, initiative and optimism were in the medium category. Based on the average score per dimension it was also found that the initiative dimension had the lowest score. These findings indicate that students still do not have the readiness to act or do something about the chances or opportunities that exist to achieve the goals set. Students who have high initiative are students who already have their own thoughts and understanding and do something based on the opportunities available. So, students' initiative in learning is related to students' awareness in doing what has been planned in achieving their learning goals consistently. Schunk et al. (2012) stated that many student learning goals on their journey will find various difficulties and problems that make it possible for students to experience failure or setback to achieve goals which will then have an impact on decreasing student learning initiatives and commitment.

Based on the results of the description of the emotional intelligence of students, it was showed that the emotional intelligence of students of class XI MIA of State High Schools in Singaraja City is in the medium category. Sequentially, the conversion scores per dimension of students' emotional intelligence from highest to lowest, such as identification 
of emotions, use of emotions, understanding emotions, and regulation of emotions. The emotional identification dimension obtained the highest score with a high category. This means that students are able to know the condition of one's own emotions toward performance and the ability to use values to make a decision. Conversely, the dimensions of emotional regulation got the lowest score compared to other dimensions of emotional intelligence in the medium category. This shows the emotional abilities of students still need to be improved to be able to manage and facilitate the achievement of learning. According to Wipperman (2007) emotion is something that tells a person about values, activities, needs about motivation, self-control spirit, and determination. Lack of students' ability to regulate emotions is caused by maturity factors that influence the development of students' emotional intelligence levels (Manimozhi \& Srinivasan, 2018).

Description of physics learning achievement in class XI MIA of Public High School in Singaraja City is in the low category. Based on the sub dimensions of knowledge, namely: conceptual and procedural, the average value of students is still in the low category. Furthermore, based on the cognitive process sub-dimension, which is understanding $(\mathrm{C} 2)$ is in the moderate category. But the sub-dimension of applying (C3) and analyzing (C4) are in the low category, even the evaluating sub-dimension (C5) is in the very low category. This can occur because understanding is opening the way to higher cognitive processes, namely: analyzing (C4), evaluating (C5), and creating (C6) (Anderson \& Krathwohl, 2001). Theoretically, the low student physics learning achievement is influenced by certain factors. Purwanto (2006) mentioned the output of the teaching and learning process is influenced by raw input, instrumental input, and environmental input. Students as raw input have a variety of different characteristics, both psychologically and physiologically. One psychological factor, namely student intelligence variables can also affect problem solving.

The results of testing the first hypothesis indicate that there is a positive relationship between learning motivation and physics learning achievement. The results of the research that have been done show the correspondence with the theories that have been studied. According to Sikhawari (2017), the key to achieve good learning achievement is high learning motivation. Motivated students will show more positive behavior and thinking than other students in order to achieve the desired results. Conversely, students who lack of motivation will not try and be enthusiastic in directing all their abilities to achieve learning goals and solve problems in the learning process (Jasobsen et al., 2009). Students will not monitor the level of understanding or ask for help when they do not understand the material being taught, thus it impacts on the lack of activities on making notes about important parts when attending lessons. Absolutely, having learning achievement will not be separated from the efforts made by teachers in providing motivation or encouragement to students in order to increase their learning motivation (Mas, 2012). Based on this, the teacher must try harder to create innovation within the students which will lead to interests, therefore, it will bring up intrinsic motivation, like students eager to learn because of their own desires. If the teacher can create innovation for the students, then students' learning success will be achieved to the maximum.

The results of the second hypothesis indicate that emotional intelligence contributes to physics learning achievement. According to Kleinginna (in Manimozhi \& Srinivasan, 2018), emotional intelligence as non-cognitive abilities, competencies and skills that affect one's ability to succeed in overcoming environmental demands and pressures. Students who can recognize their own emotions tend to be able to control their emotions and find the best solution to overcome these emotions, so that they will not easily give up with difficulties, not easily angry, offended, and not easily stressed when facing a problem. Students also have the ability to motivate themselves to improve by using social relation to ask questions and try to find a way about difficulties in learning. The ability to build relationships and good emotional regulation is also functioning, so that the student is able to develop into a person who is strong and has brilliant learning achievements. Based on this, emotional intelligence must also be developed with some adequate techniques, such as discussion, counseling, opening insights to the world wide, and others (Mandal, 2017). If this is applied, it can enhance students' understanding abilities, reflect on themselves and their attention, which in turn also increases their learning achievement.

The third hypothesis results found a positive relationship together between learning motivation and emotional intelligence with student physics learning achievement. In the process of learning physics, students sometimes find obstacles or failures. If students have low motivation to learn, 
students will quickly giving up or surrender to the failures or difficulties they face. Likewise, if students have high emotional intelligence, then it is likely that these students can solve the problems they face well. This means that emotional intelligence that students have also plays an important role in determining student success in learning.

Other interesting results that can be found in this study are the students' motivation and emotional intelligence in the medium category, but the physics learning achievement results are in the low category. In accordance with the theoretical studies that have been presented, it should be like if students' learning motivation and emotional intelligence scores are higher, the learning achievement results will also be higher. This shows the gap in the contribution of predictors to the criteria that can be caused by the contribution of other variables outside this study. This is also supported by the effective contribution of the two predictors to the criterion variable, which is $7 \%$. The remaining $93 \%$ is influenced by various other variables outside the study. This gap can also be caused by fatigue and boredom of students in answering questionnaires and achievement tests given. In addition, students assume that the results of the questionnaire and tests given do not affect their grades in school. The findings in this study should be used as a reference for teachers and students in the learning process in class.

\section{CONCLUSIONS AND SUGGESTIONS}

\section{Conclusions}

Based on the research that has been carried out, some conclusions can be drawn as follows. (1) There is a positive and significant relationship between learning motivation and physics learning achievement of XI MIA grade students of SMA Negeri in Singaraja. The effective contribution of learning motivation towards students' physics learning achievement is $5.82 \%$. (2) There is a positive and significant relationship between emotional intelligence and physics learning achievement of students in class XI MIA at SMA Negeri Singaraja. The effective contribution of emotional intelligence to students physics learning achievement which is $1.18 \%$. (3) There is a positive and significant relationship jointly between learning motivation and emotional intelligence with physics learning achievement of students of class XI MIA in SMA Negeri Singaraja. The effective contribution of learning motivation and emotional intelligence together to students' physics learning achievement is $7 \%$.

\section{Suggestion}

As for some suggestions that can be submitted as a follow up from the results of this study are as follows. (1) For principals, as leaders in schools, to pay attention and consider aspects of student motivation and emotional intelligence as a reference in improving curriculum implementation in schools, so that later on the learning process will provide maximum results. (2) For physics teachers, as an effort to improve learning motivation, emotional intelligence, and student physics learning achievement is firstly the teacher can help to develop student learning motivation externally through social rewards. Secondly, emotional intelligence must also be developed with some adequate techniques, such as discussion, counseling, opening insights to the world wide, and so on. Third, teachers must also pay attention to and understand the 2013 Curriculum studies contained $\mathrm{KI}$ and $\mathrm{KD}$ in the syllabus used to be able to improve student learning achievement.

\section{ACKNOWLEDGEMENTS}

Researchers say thank you to Prof. Dr. I Wayan Santyasa, M.Sc. as supervisor I and at the same time as academic supervisor, Dr. Ni Ketut Rapi, M.Pd. as supervisor II and Coordinator of the Physics Education Study Program, I Putu Eka Wilantara, M.Pd. as the head of Singaraja 1 High School, Drs. I Made Arya Kartawan, M.Pd. as the head of SMA Negeri 2 Singaraja, Made Sri Astiti, S.Pd., M.Pd. as the head of SMA 3 Singaraja, and Putu Gede Journalist, S.Pd., M.Pd. as the head of SMA 4 Singaraja who have given permission to the author to carry out research in the school they lead.

\section{REFERENCES}

Agustina, Y., \& Yuliana. (2018). Pengaruh motivasi dan minat belajar terhadap prestasi belajar siswa di SMP Negeri 1 Peusangan Kabupaten Bireuen. Jurnal Sains Ekonomi dan Edukasi, 6(1), 1-7. Tersedia pada www.jfkip.ac.id. Diakses 20 Oktober 2018.

Anderson, L. W., \& Krathwohl, D. R. (2001). Kerangka landasan untuk pembelajaran, pengajaran, dan assessment: Revisi taksonomi pendidikan Bloom. Terjemahan Agung Prihantoro. Yogyakarta: Pustaka Pelajar.

Asry, W., Jaya, I., \& Lubis, L. (2017). The influence of emotional intelligence and achievement motivation to learning achievement of akidah 
akhlak subject at Madrasah Aliyah Negeri 1 Medan. Journal of Humanities And Social Science, 22(8), 62-69. Tersedia pada www. iosrjournals.org. Diakses pada 19 Oktober 2018.

Daud, F. (2012). Pengaruh Kecerdasan Emosional (EQ) dan Motivasi Belajar terhadap Hasil Belajar Biologi Siswa SMA 3 Negeri Kota Palopo. Jurnal Pendidikan dan Pembelajaran, 2(19), 243- 255. Tersedia pada www.journal.um.ac.id. Diakses pada 23 Mei 2019.

Goleman, D. (2003). Kecerdasan emosi untuk mencapai puncak prestasi. Jakarta: PT Gramedia Pustaka Utama.

Hamalik, O. (2001). Proses belajar mengajar. Bandung: Bumi Aksara.

Jasobsen, D. A., Eggen, P. \& Kauchak, D. (2009). Method for teaching: Promoting student learning in K-12 classrooms eighth edition. Boston: Pearson Education, Inc.

Kemendikbud, (2003). Undang-Undang Nomor 20 Tahun 2003 tentang Sistem Pendidikan Nasional. Jakarta: Kementerian Pendidikan dan Kebudayaan.

Kemendikbud, (2014). Lampiran peraturan menteri pendidikan dan kebudayaan RI nomor 59 tahun 2014 tentang kurikulum 2013 sekolah menengah atas/madrasah aliyah. Jakarta: Kementerian Pendidikan dan Kebudayaan.

Kemdikbud, (2018). Rekap hasil ujian nasional UN tingkat sekolah. Tersedia pada https://puspendik. kemdikbud.go.id/hasil-un/. Diakses 24 Mei 2019

Liu, A. N. A. M., \& Surat, S. I. (2017). Hubungan kecerdasan emosional dengan hasil belajar fisika semester 2 pada peserta didik kelas X SMAK St. Petrus Ende tahun pelajaran 2016/2017. Jurnal Pendidikan MIPA, 7(2), 107-114. Tersedia pada www.jurnalpendidikanmipa.com. Diakses 19 Oktober 2018.

Mandal, M. B. (2017). Emotional intelligence and academic achievements of upper primary rural students in relation to their gender, family type and economic class. Journal of Research \& Method in Education. 7(1): 48-53. Tersedia pada www.iosrjournals.org. Diakses 11 Mei 2018.

Manimozhi, G. \& Srinivasan, P. (2018). Emotional intelligence and academic achievement: A metaanalysis. American Journal of Educational Research, 6(7), 1051-1055. Tersedia pada http:// pubs.sciepub.com//. Diakses 19 Oktober 2018.

Mas, S. R. (2012). Hubungan Kompetensi Personal dan Profesi Guru dengan Motivasi Belajar Siswa di
SMKN 2 Kota Gorontalo. Jurnal Pendidikan dan Pembelajaran, 2(19), 212- 218. Tersedia pada www.journal.um.ac.id. Diakses pada 23 Mei 2019

Muwonge, C. M., Ssenyonga, J., \& Kwarikunda, D. (2018). Cognitive appraisals, achievement emotions, and motivation towards learning mathematics among lower secondary student. African Journal of Research in Mathematics, Science and Technology Education, 22(2), 243253. Tersedia pada https://doi.org/10.1080/18117 295.2018.1487907. Diakses 19 Oktober 2018.

Nur, M. (2003). Pemotivasian siswa untuk belajar. Surabaya: Universitas Negeri Surabaya.

Purwanto, M. N. (2006). Psikologi Pendidikan. Bandung: PT Remaja Rosdakarya.

Ramirez, A., Arellano, Bory, J., Reyes, Hernandez, L. M., \& Simon. (2018). Emotion, motivation, cognitive-metacognitive strategies, and behavior as predictors of learning performance in blended learning. Journal of Educational Computing Research, 57(1), 1-23. Tersedia pada http:// journals.sagepub.com/. Diakses pada tanggal 15 Februari 2018.

Santyasa, I W. (2014). Asesmen dan evaluasi pembelajaran fisika. Singaraja: Universitas Pendidikan Ganesha.

Schunk, D. H., Pintrich, P. R., \& Meece, J. L. (2012). Motivasi dalam pendidikan: Teori, penelitian, dan aplikasi edisi ketiga. Terjemahan: Motivation in education: Theory, research, and applications third edition, oleh: Ellys Tjo. Jakarta: PT Indeks.

Sikhwari, T. D. (2017). A study of the relationship between motivation, self-concept and academic achievement of students at a University in Limpopo Province, South Africa. International Journal of Educational Sciences, 6(1), 19-25. Terdapat pada http://www.tandfonline.com/loi/ reds20. Diakses 19 Oktober 2018.

Slameto, (2003). Belajar dan faktor-faktor yang mempengaruhinya. Jakarta: Rineka Cipta.

Soemanto, W. (2003). Psikologi Pendidikan. Bandung: Rineka Cipta.

Suryabrata, S. (2011). Psikologi pendidikan. Jakarta: PT Raja Grafindo Persada.

Wipperman, J. (2007). Meningkatkan kecerdasan emosional. Jakarta: PT Prestasi Pustakaraya.

Yuliawan, A. (2016). Hubungan antara motivasi belajar dan latar belakang pendidikan dengan prestasi belajar mahasiswa. Jurnal Profesional Islam, 14(1), 15-24. Tersedia pada https://ejournal. stikespku.ac.id/. Diakses 20 Oktober 2018. 